\title{
Risk Factors for Early Childood Caries: A cross- sectional study in a Dental School
}

\section{Erken Çocukluk Çağı Çürüğü Risk Faktörleri: Kesitsel Bir İnceleme}

\author{
Mustafa KAYA id, Seda METE MANDACI ${ }^{2}$ id, Betül KARGÜL2 id \\ ${ }^{1}$ Department of Pedodontics, Bezmialem Vakif University School of Dentistry, İstanbul, Turkey \\ ${ }^{2}$ Department of Pedodontics, Marmara University School of Dentistry, İstanbul, Turkey
}

\section{ABSTRACT}

Objective: This study aimed to investigate possible early childhood caries (ECC) risk indicators in preschoolers who applied for examination/treatment at the Government University Pediatric Dentistry Clinic, İstanbul, Turkey.

Material and Methods: Children aged 36-71 months and their mothers who applied for examination/treatment and consented were enrolled in this cross-sectional survey during a 3-month period. Mother-child pairs were examined intraorally, and caries experience was recorded using ( $\mathrm{dmft} / \mathrm{DMFT})$ an index. A structured questionnaire inquiring oral hygiene habits and diet history of the children was employed to interview the mothers. Categorical data from children with no clinical caries (NC), ECC, Severe ECC (S-ECC) were compared using Chi-square test and correlation of caries experience in mother-child pairs and were tested with Spearman rho. Statistical significance was set $\mathrm{p}<0.05$.

Results: Two hundred sixty-six children $(4.41 \pm 0.87$ years old $)$ were enrolled in the study. Forty $(15.04 \%)$ children were diagnosed with ECC, 209 with S-ECC and 17 had NC. Breastfeeding was practiced by $255(96.2 \%)$ mothers, but the duration was not different among groups. There was no significant association with breastfeeding beyond 24 months and caries ( $\mathrm{p}=0.743)$. Children with S-ECC were snacking more frequently with sweets than ECC ( $\mathrm{p}=0.012)$. The number of mothers with a visible dental plaque was higher in S-ECC than ECC $(\mathrm{p}<0.01)$. Maternal DMF-T scores significantly correlated with their children's dmf-t in the whole sample $(r=0.547, \mathrm{p}<0.01)$.

Conclusion: Preventive measures should begin from pregnancy and focus on oral health/hygiene education to mothers to avoid the devastating effects of ECC.

Keywords: Dental Caries, breastfeeding, bottle feeds, oral health

\section{öz}

Amaç: İstanbul İlindeki bir Devlet Üniversitesi Pedodonti kliniğine başvuran çocuklarda erken çocukluk çağı çürüğü (ECC) risk faktörlerinin incelenmesidir.

Yöntem: Bu kesitsel çalışmaya 3 aylık süre içinde muayene/ tedavi edilen ve katılım için onam veren 36-71 ay arası çocuklar ve anneleri dahil edildi. Anne ve çocukların ağız içi muayeneleri yapılıp çürük durumu (d/D: çürük, m/M: eksik, f/F: dolgulu) dmf- t/DMF- T indeksleri ile belirlendi. Çocukların beslenme, ve ağız hijyen alışkanlıkları anket ile görüşme şeklinde kaydedildi. Çürüksüz (NC), ECC ve Şiddetli ECC (S- ECC) olarak belirlenen çocuklar arası kategorik verilerin karşılaştırılması $\mathrm{Ki}$ kare testi, anne- çocuk çiftlerinde çürük indeksleri arasındaki ilişki Spearman korelasyon testi ile değerlendirildi. İstatistiksel anlamlılık $\mathrm{p}<0.05$ olarak kabul edildi.

Bulgular: İki yüz altmış altı ( $4.41 \pm 0.87$ yaş) çocuk çalışmaya dahil edildi. Kırk çocuk ECC, 209 S- ECC, 17 çocuk çürüksüz olarak saptandı. $255(\% 96,2)$ çocuğun anne tarafından emzirildiği görüldü ancak bu süre gruplar arasında fark göstermedi. 24 aydan daha uzun emzirmeyle diş çürüğü arasında ilişki saptanmadı $(\mathrm{p}=0.743)$. Şekerli gıdalarla atıştırma sıklığı S- ECC grubunda ECC'den fazla bulundu $(\mathrm{p}<0.01)$. Görünür dental plak bulunan anne sayısı S- ECC'li çocularda ECC'den fazlaydı $(\mathrm{p}<0.01)$. Annenin DMF- T skoru çocuklarının dmf- t’leriyle anlamlı ilişki gösterdi $(r=0.547, \mathrm{p}<0.01)$.

Sonuç: Okul öncesi çocukların oral hijyen ve diş sağlığı üzerinde anne etkindir. ECC'nin yıkıcı etkilerini engellemek için koruyucu hekimlik uygulamaları gebelikten başlayıp, ağız sağlığı/hijyen eğitimine odaklanılmalıdır.

Anahtar Kelimeler: Diş çürükleri, emzirme, biberon beslenmesi, ağız sağlığı

\section{Introduction}

Early Childhood Caries (ECC) is a common public health problem of global proportions, especially for those living in the developing world. Although dental caries has shown an overall decline worldwide, it remains a problem amonga large number of preschoolers $(1,2)$. 
Starting with smooth-surface carious lesions on primary maxillary incisors, it quickly spreads to the remaining teeth, causing severe impairment of the dentition. Pain, infection, eating difficulties, and challenges on treating the affected young children makes ECC a complex dental problem (3).

Early Childhood Caries prevalence in literature from developed countries is at $1 \%-12 \%$, whereas up to $70 \%$ prevalence has been reported in developing countries $(4,5)$. Although different studies reveal different percentages, socioeconomically disadvantaged children are the most severely affected (6). Countrywide and local studies showed similar high-level prevalence in Turkey. A study by Namal et al. reported a $74 \%$ prevalence of caries in 3-6-year-olds (7).

Early Childhood Caries is a chronic, transmissible, infectious disease with a multifactorial etiology (8). Dietary factors significantly associated with ECC include frequency, timing, and amount of sugar consumption (9). Specific dietary factors include daily sucrose intake, nighttime feeding, frequent consumption of sugary drinks (particularly juice) and carbonated drinks, amount and frequency of the sweet intake, frequent feeding during the day (10-12). Complex interactions between the use of sweetened pacifiers, breastfeeding on demand, neglected oral hygiene, Streptococcus mutans (MS), maternal education and dental health awareness, family structure, and social status make its etiology complex (9).

Other factors associated with ECC include genetic predisposition and parental education as well as nutritional, environmental, socioeconomic, and parental style factors (13). Education level is considered an important socioeconomic indicator, and maternal education level is related to the prevalence of dental caries $(9,12)$.

The most likely suspected causative agent for ECC is Streptococcus mutans (MS). Establishment and expression of its infection depend on diet and transmission. MS may be transmitted from a vertical or a horizontal source. Maternal saliva is the primary source for vertical MS transmission for children (4). Factors related to infant feeding practices, such as frequent exposure to sugar, frequent snacking, feeding sweetened drinks in bed, and sharing foods with adults as well as maternal caries status, oral hygiene, and dietary habits predispose to early MS colonization and establishment of high MS counts. Vertical transmission is the main route for MS colonization. Evidence for horizontal transmission may also be important owing to socioeconomic changes in the Western culture i.e., the use of daycare facilities when both parents are employed $(4,14)$.

Our study aimed to investigate possible risk indicators, feeding habits of preschoolers, and maternal oral health in Istanbul, Turkey.

\section{Methods}

\section{Sample size calculation}

According to a previous pilot study conducted at our department $(80 \%$ caries prevalence with $5 \%$ error and $95 \%$ confi- dence interval) minimum sample size was determined as 243 subjects.

\section{Study population}

This study was conducted at the Marmara University, Department of Pediatric Dentistry for a period of 3 months (September-December 2014) in children aged 36-71 months fulfilling the eligibility criteria and whose parents provided written consent to participate after its purpose was explained. Socioeconomically disadvantaged children comprise the majority of the patient profile. Systematically healthy children that have completed their primary teeth eruption and mothers of the children that were diagnosed with ECC were included in the study. Two hundred sixty-six children were enrolled. Children and ECC mothers were clinically examined, and a structured questionnaire was filled. Ethical approval was obtained from the Marmara University Ethical Committee $(16.11 .2012 / 129)$.

\section{Eligibility Criteria:}

- Age, 36-71 months.

- Mother should be present during examination.

- Child's verbal assent.

- Completed primary dentition.

- No history of systemic illness.

\section{Survey and clinical examination}

Two dentists filled out a questionnaire (Table 1) by interviewing mothers during the visit. Two calibrated examiners conducted clinical exams, and the kappa value was 0.8 tested on 25 children out of the sample. (MS, KS). To avoid potential bias, the same interviewer did not perform oral examinations. The child/mother was seated on a dental chair, and dental examination was performed on dry surfaces; cavitated and visible carious teeth were noted according to World Health Organization criteria (15) on the examination form; DMFT and $\mathrm{dmft}$ scores were recorded. Each child was classified as follows:

1. No clinical caries (NC)

2. With Caries

a) ECC: Presence of one or more decayed, missing, or filled tooth surfaces in any primary tooth in a child under 6 yrs of age.

b) Severe ECC (S-ECC): Decayed, missing, or filled scores of $\geq 4$ (ages 3 to $<4$ ), $\geq 5$ (ages 4 to $<5$ ), or $\geq 6$ (ages 5 to $<6)(8)$.

The results were reviewed from both disease perspective as caries/NC and according to AAPD ECC criteria to study specific clinical features of this diagnosis approach (NC/ECC/SECC).

Descriptive statistics for continuous variables were reported as mean \pm standard deviation and median (minimum- maximum). Independent and nonnormally distributed data were analyzed using Kruskal Wallis, post hoc Mann-Whitney U 
Test with Bonferroni corrections for three groups, and MannWhitney U Tests for two group comparisons. Categorical variables were compared for statistical differences across groups using $\mathrm{X}^{2}$ tests and Fisher's exact tests. Spearman's rho was used for correlations. Statistical significance was set $\mathrm{p}<0.05$. Statistical analyses were performed using MedCalc Statistical Software version 12.7.7 (MedCalc Software bvba, Ostend, Belgium; http://www.medcalc.org; 2013).

\section{Results}

\section{Demographic data}

Two hundred sixty-six children (mean age \pm standard deviation, $4.41 \pm 0.87$ ) were enrolled in the study (Figure 1). Forty (15.04\%) children (17 girls and 23 boys) were diagnosed with ECC, 209 (78.57\%; 77 girls, 132 boys) with S-ECC, and $17(6.39 \%)$ children (10 girls and 7 boys) had NC. Gender

\section{Table 1. Contents of the questionnaire}

\section{Demographic Data}

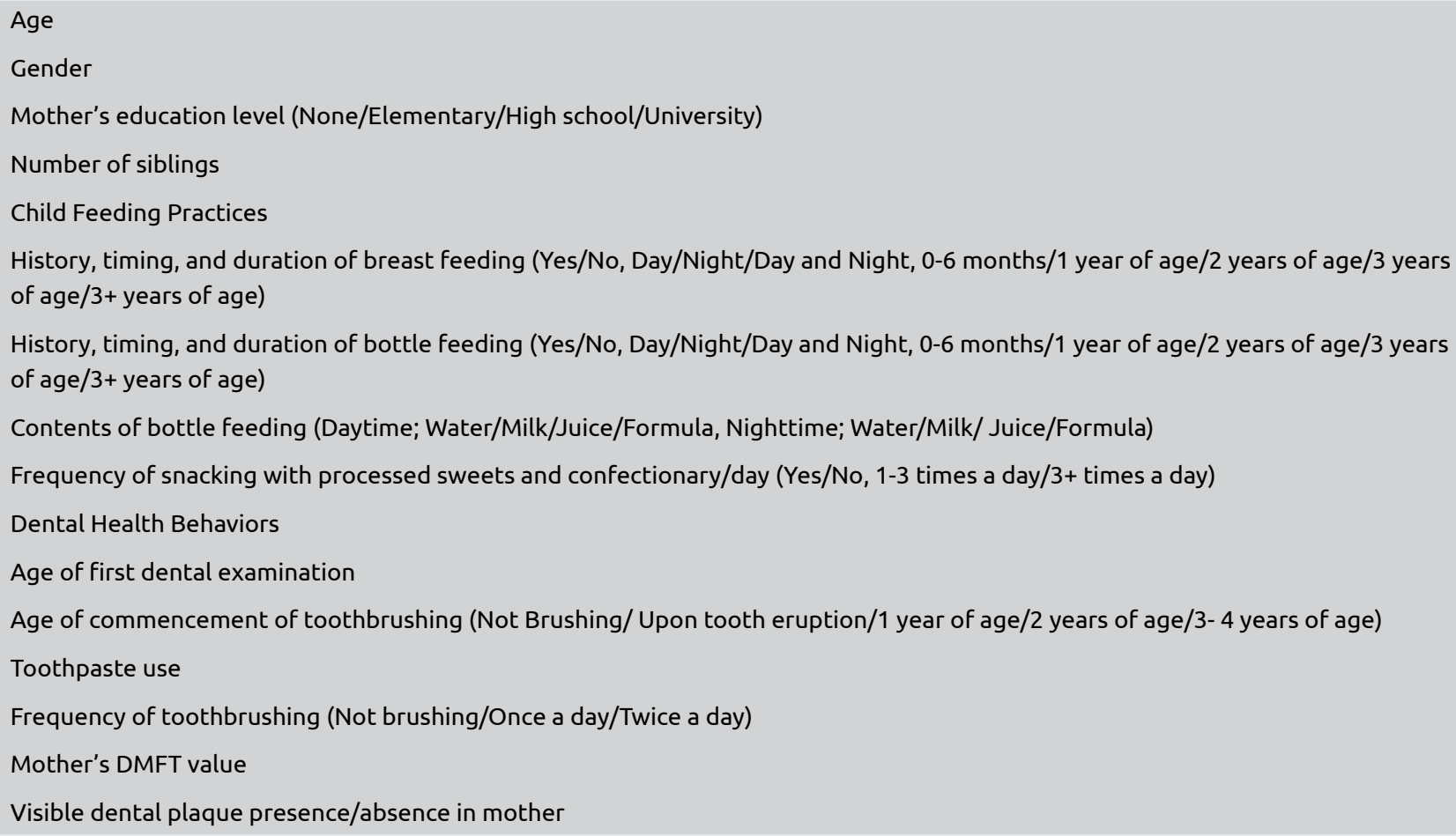

\begin{tabular}{|l|c|c|c|c|c|c|c|} 
& None & $0-6$ months & Age 1 & Age 2 & Age 3 & Age 3+ & Total \\
\hline NC & $2(11.8)$ & $4(23.5)$ & $4(23.5)$ & $5(29.4)$ & $1(5.9)$ & $1(5.9)$ & $17(100)$ \\
ECC & $3(7.5)$ & $11(27.5)$ & $6(15)$ & $12(30)$ & $7(17.5)$ & $1(2.5)$ & $40(100)$ \\
SECC & $5(2.4)$ & $37(17.7)$ & $39(18.7)$ & $89(42.6)$ & $32(15.3)$ & $7(3.3)$ & $209(100)$ \\
Total & $10(3.8)$ & $52(19.5)$ & $49(18.4)$ & $106(39.8)$ & $40(15)$ & $9(3.4)$ & $266(100)$ \\
\hline Fisher's Exact & & & & & &
\end{tabular}

Table 3. Daytime/Nighttime bottle content

\begin{tabular}{|c|c|c|c|c|c|c|c|c|c|c|c|c|}
\hline & \multicolumn{6}{|c|}{ Daytime } & \multicolumn{6}{|c|}{ Nighttime } \\
\hline & \multicolumn{2}{|c|}{ Milk } & \multicolumn{2}{|c|}{ Juice } & \multicolumn{2}{|c|}{ Formula } & \multicolumn{2}{|c|}{ Milk } & \multicolumn{2}{|c|}{ Juice } & \multicolumn{2}{|c|}{ Formula } \\
\hline & No & Yes & No & Yes & No & Yes & No & Yes & No & Yes & No & Yes \\
\hline ECC & $39(97.5)$ & $2(2.5)$ & $40(100)$ & 0 & 39 (97.5) & $1(2.5)$ & $39(97.5)$ & $1(2.5)$ & $40(100)$ & 0 & 39 (97.5) & $1(2.5)$ \\
\hline S- ECC & $123(58.9)$ & $86(41.1)$ & $166(79.4)$ & $43(20.6)$ & $154(73.7)$ & 55 (26.3) & $160(76.6)$ & 49 (23.4) & $202(96.7)$ & $7(3.3)$ & $188(90)$ & $21(10)$ \\
\hline$p$ & $<0.01$ & $<0.01$ & $<0.01$ & $<0.05$ & $>0.05$ & $>0.05$ & & & & & & \\
\hline
\end{tabular}




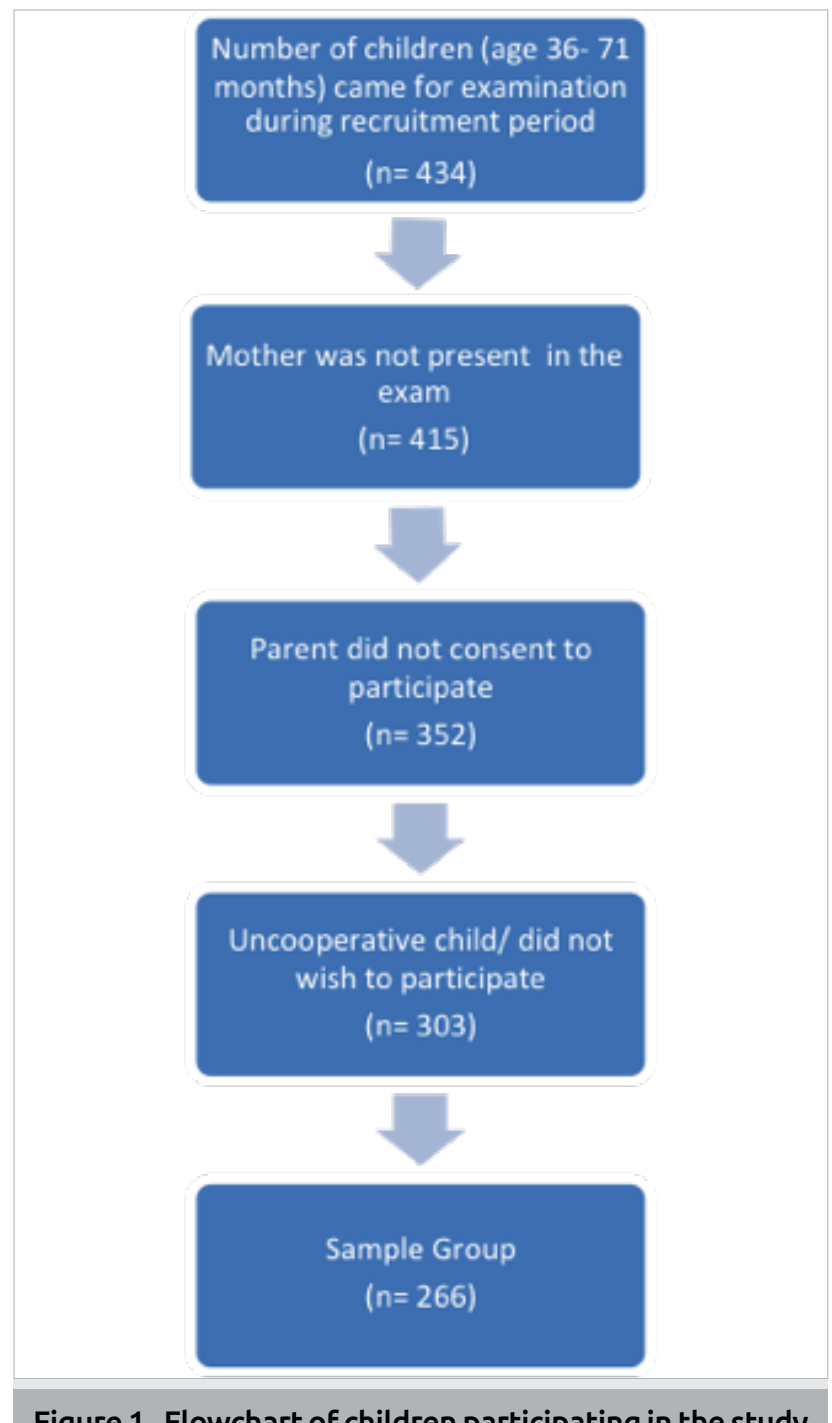

Figure 1 . Flowchart of children participating in the study

distribution was not different between groups $(\mathrm{p}=0.181)$. Median dmft (min-max) for ECC group was 3 (1-5) and 10 (4-20) for the S-ECC group (3). Age was not different among groups $(\mathrm{p}=0.36)$; however, the $\mathrm{dmft}$ of children was significantly different between groups $(\mathrm{p}<0.01)$. Majority of the mothers $(57.7 \%)$ and fathers $(50.6 \%)$ were primary school graduates. Parental education level was not different from NC, ECC, and S-ECC diagnoses (Fisher's exact test, $\mathrm{p}=0.888$ and $\mathrm{p}=0.104$, respectively).

\section{Child feeding/Dietary practices}

Two hundred and fifty-five (96.2\%) mothers in the entire sample practiced breastfeeding. Duration of breastfeeding was not statistically different among groups. (Table 2) There was no significant association between breastfeeding beyond 24 months and caries (Fisher's exact test, $\mathrm{p}=0.743$ ).

Overall, 178 (66.91\%) children were bottle-fed: 28 (10.52\%) children with ECC, 140 (52.63\%) with S-ECC, and 11 (4.14\%) NC. The timing of bottle feeding (daytime/ nighttime/both) was not different among the study groups (Fisher's exact test $=0.873$ ). The number of children bottle-fed with water, milk, fruit juice, and formula were higher in S-ECC group than ECC group during day time. Nighttime fruit juice and formula were not different between S-ECC and ECC but milk was more common in S-ECC group $(\mathrm{p}=0.002)$ (Table 3).

The majority $(94.7 \%)$ of children were snacking between meals in the whole sample. Times of snacking between meals was not different among the three groups $(p=0.258)$. Children diagnosed with S-ECC were snacking more frequently with sweets more than ECC children during the day $(\mathrm{p}=0.012)$.

\section{Dental health behaviors}

The median age of children at the first dental visit was statistically different among the groups $(p=0.002)$. The first dental visit to S-ECC kids was significantly earlier than ECC and NC $(\mathrm{p}<0.05)$. Time for beginning tooth brushing (started eruption/age 1/age 2/age 3) was not different among all groups $(\mathrm{p}=0.889)$. The frequency of the tooth brushing was no different among the three groups $(\mathrm{p}=0.44)$ and $82 \%$ of the children were using toothpaste for brushing but this was not different from groups $(\mathrm{p}=0.155)$.

Hundred and thirty-two children had at least one sibling; half of the families $(49.6 \%)$ had two children. The frequency of single kids versus kids with at least one sibling was not significantly different from the three groups $(\mathrm{p}=0.548)$. Median DMF-T scores: 0 (0-18) for ECC group mothers were significantly higher than S-ECC mothers: $8(0-21)(\mathrm{p}<0.001)$. The number of mothers with visible dental plaque (Fisher's exact, $\mathrm{p}<0.01)$ and median DMFT scores $(\mathrm{p}<0.001)$ was higher in S-ECC than ECC. Maternal DMF-T scores significantly correlated with their children's dmf-t in the entire sample $(\mathrm{r}=0.547, \mathrm{p}<0.01)$. Although majority of the mothers $233(90 \%)$ do not put their infant's pacifier or feeding bottle in their mouth, nearly half of the mothers admitted (44.2\%) they do not refrain from tasting their kids meal with his/her spoon, which is significantly higher in S-ECC group than ECC group $(\mathrm{p}<0.01)$.

\section{Discussion}

Epidemiological studies show that the ECC prevalence varies from population to population; however, disadvantaged children, regardless of race, ethnicity or culture, are the most vulnerable (16). Our study was conducted at a governmentfunded University Clinic in Istanbul, which is the most densely populated city in the country. Majority of the patients were referred from all over the city for their extensive dental treatment needs. The participants of our study were routine incoming patients seeking advanced dental treatment covered by government insurance for children below 18 years of age. This level of caries prevalence is higher than $69.8 \%$ caries prevalence reported by Gokalp et al. (17) and 70.5\% reported by Olmez et al. (18) in children of similar age.

Breastfeeding presents immunological, nutritional, and psychological advantages. Although breast milk is noncariogenic, 
it does contain lactose, which can be used by cariogenic bacteria to produce acids $(19,20)$. Ad libitum breastfeeding or breastfeeding for longer duration decreases the plaque $\mathrm{pH}$ and thereby increases the risk of ECC (21). A regression analysis performed by Nunes et al. (11) reported that prolonged breastfeeding per se was not a risk factor of ECC. Duration of breastfeeding was not different among groups in our study, similar to the study conducted by Paglia et al (2). The association with caries and a child ever breastfed should be interpreted with accompanying dietary habits.

Caries depend on multiple factors; however, diet and oral hygiene are two of the highest ranked. Owing to the historical evolution of the ECC concept, baby bottle use has been inquired in many studies and recommended by the AAPD to be used without sugar-containing liquids $(8,10-12,18)$. Bottle feeding was practiced by $66.91 \%$ in the whole sample and the duration or timing was not different between groups. Bottle use, particularly with sweetened liquids has been associated with ECC in the literature $(12,22)$. However, this is reported not to be an implementing factor of all cases (23).

Frequent snacking increases the acidogenic/aciduric bacteria colonization and subsequently leads to the dominance of the MS, with the progression of caries lesions (9). The increased amount of sugar snacks and its between meal consumption are significant caries risk factors (24). Snacking frequency between meals was not different from our study but higher in S-ECC than ECC. According to Rosenblatt et al. (10), the prevalence of caries and the number of sugary snacks between meals and a cariogenic diet were strongly related to ECC.

The questionnaire method is a common methodology used in ECC studies and is a shortcoming in our study $(12,25)$. This method of history taking to depend on mother's recollection of the past and motives of social desirability may cause information bias. The other shortcoming of our study is the lack of microbiological evidence to support MS transmission of the mother similarly by Agarwal et al. (9). Parents influence on their children's oral hygiene and eating preferences has been reported repeatedly, but the motives behind those actions are unknown to the dental community (5). Examining parental rearing styles concerning child's oral health beyond socioeconomic status and emphasizing on child-parent interaction may shed more light on this issue.

According to King et al. (26), most children receive the benefit of oral hygiene practice in their first year. There was only a marginal increase in the caries prevalence of those children in whom initiation of tooth brushing/cleaning was delayed $(26,27)$. Majority of the children started toothbrushing after 3 years of age, and initiation time was not different between study groups in our study.

Being the primary caretaker of the child makes the mother influential on the eating and oral hygiene practices of the child (28). Besides her influence on eating and oral hygiene, moth- ers are also a potential source for MS transmission if they engage in practices such as tasting the infant's food and sharing eating utensils (29). Higher maternal DMFT scores were reported on ECC compared with children without caries previously (2), and this result was reaffirmed between ECC and S-ECC mothers in our study. Salivary transmission link has been established more than three decades ago; unfortunately, a significant portion of the mothers in our study share utensils for tasting their child's meal and this behavior is significantly higher in S-ECC group than ECC.

Mother-child oral hygiene levels correlated in our study similiar to Mohebbi et al (25). Mother's caries experience was moderately correlated to their children's caries level in agreement with Zanata et al. (30) and Agarwal (9). Caries experience correlation between mother-child pairs may be the result of both salivary transmission and maternal neglect towards their child's oral hygiene. Preschool children's hand dexterity is generally accepted as insufficient to effectively perform toothbrushing; thus, parental assistance is necessary $(20,31)$. Although we failed to measure parental supervision during tooth brushing, the disproportion between reported child tooth brushing frequency and caries experience of the sample might have been effected by it.

The first dental visit is recommended before 12 months of age; still, data indicate that approximately $9 \%$ in the USA and $40 \%$ of 3-4-year-olds in Australia are taken to a dental Professional (1). In our study, the median age of the children with ECC at the first dental visit was 4 years, and the age of the first visit was not different from study groups. This represents the country's habit of seeking dental care when and if dental pain occurs $(32,33)$. But the situation is also a paradox considering the frequent checkups at young ages performed by pediatricians.

In Turkey, the government took a step in 2008 to provide access to primary health care for all citizens. In these clinics, medical doctors provide basic exams, vaccinations, and referral to advanced facilities if necessary. To change this caries trend in the country in the years to come integration of dental exams to children's regular medical visits and reaching out to non-dental medical professionals to create awareness can be considered.

Early childhood caries has been reported by numerous researchers in varying degrees in Turkey $(7,18,34)$. Caries harm the child's physical health, emotional wellbeing and also burden the healthcare system economically. Parental influence on their children's caries experience is certain; however, the motives behind those actions are unknown to the dental community. Parental rearing styles concerning the child's oral health need to be examined beyond socioeconomic status with the inclusion of child-parent interaction. Evidence for this current study can be used to help caries prevention in the future and risk minimization activities in preschool children. 


\section{Conclusion}

Mother's influence on oral hygiene and health was apparent in preschoolers with caries. Preventive measures should begin from the pregnancy and focus on oral health/hygiene education to mothers to avoid its devastating effects.

Ethics Committee Approval: Ethics committee approval was received for this study from the ethics committee of the Marmara University (Protocol Number:129).

Informed Consent: Written informed consent was obtained from the parents of the patients who participated in this study.

Peer-review: Externally peer-reviewed.

Author Contributions: Concept - B.K.; Design - B.K.; Supervision - B.K.; Fundings - B.K., S.M., S.K.; Data Collection and/or Processing - S.M., S.K.; Analysis and/or Interpretation - B.K., S.M., S.K.; Literature Search - B.K., S.M., S.K.; Writing Manuscript - S.M., S.K.; Critical Review - B.K., S.K.

Conflict of Interest: The authors have no conflicts of interest to declare.

Financial Disclosure: The authors declared that this study has received no financial support.

Etik Komite Onayı: Bu çalışma için etik komite onayı Marmara üniversitesi Etik Kurulu 'ndan (129) alınmıştır.

Hasta Onamı: Yazılı hasta onamı bu çalışmaya katılan hastaların ailelerinden alınmıştır.

Hakem Değerlendirmesi: Dış bağımsız.

Yazar Katkıları: Fikir - B.K.; Tasarım - B.K.; Denetleme - B.K.; Kaynaklar - B.K., S.M., S.K.; Veri Toplanması ve/veya İşlemesi - S.M., S.K.; Analiz ve/veya Yorum - B.K., S.M., S.K.; Literatür Taraması - B.K., S.M., S.K.; Yazıyı Yazan - S.M., S.K.; Eleştirel İnceleme - B.K., S.K.

Çıkar Çatışması: Yazarlar çıkar çatışması bildirmemişlerdir.

Finansal Destek: Yazarlar bu çalışma için finansal destek almadıklarını beyan etmişlerdir.

\section{References}

1. Arora $\mathrm{A}^{1}$, Schwarz E, Blinkhorn AS. Risk factors for early childhood caries in disadvantaged populations. J Investig Clin Dent 2011; 2: 223-8 [CrossRef]

2. Paglia L, Scaglioni S, Torchia V, De Cosmi V, Moretti M, Marzo G, et al. Familial and dietary risk factors in Early Childhood Caries. Eur J Paediatr Dent 2016; 17: 93-9.

3. Ismail Al. Determinants of health in children and the problem of early childhood caries. Pediatr Dent 2003; 25: 328-33.

4. Fung MHT, Wong MCM, Lo ECM, Chu CH. Early Childhood Caries: A Literature Review. J Oral Hyg Health 2013; 1: $1-7$.
5. Hooley M, Skouteris H, Boganin C, Satur J, Kilpatrick N. Parental influence and the development of dental caries in children aged 0-6 years: a systematic review of the literature. J Dent 2012; 40: 873-85. [CrossRef]

6. Berkowitz RJ. Causes, treatment and prevention of early childhood caries: a microbiologic perspective. J Can Dent Assoc 2003; 69: 304-7.

7. Namal N, Vehit HE, Can G. Risk factors for dental caries in Turkish preschool children. J Indian Soc Pedod Prev Dent 2005; 23: 115-8. [CrossRef]

8. American Academy of Pediatric Dentistry. Policy on Early Childhood Caries (ECC): Classifications, Consequences, and Preventive Strategies. Pediatr Dent 2016; 37: 50-2.

9. Agarwal V, Nagarajappa R, Keshavappa SB, Lingesha RT. Association of maternal risk factors with early childhood caries in schoolchildren of Moradabad, India. Int J Paediatr Dent 2011; 21: 382-8. [CrossRef]

10. Rosenblatt A, Zarzar P. Breast-feeding and early childhood caries: an assessment among Brazilian infants. Int J Paediatr Dent 2004; 14: 439-45. [CrossRef]

11. Nunes AM, Alves CM, Borba de Araujo F, Ortiz TM, Ribeiro MR, Silva AA, et al. Association between prolonged breastfeeding and early childhood caries: a hierarchical approach. Community Dent Oral Epidemiol 2012; 40: 542-9. [CrossRef]

12. Hallett KB, O'Rourke PK. Social and behavioural determinants of early childhood caries. Aust Dent J 2003; 48: 27-33. [CrossRef]

13. Qin M, Li J, Zhang S, Ma W. Risk factors for severe early childhood caries in children younger than 4 years old in Beijing, China. Pediatr Dent 2008; 30: 122-8.

14. Vadiakas G. Case definition, aetiology and risk assessment of early childhood caries (ECC): a revisited review. Eur Arch Paediatr Dent 2008; 9: 114-25. [CrossRef]

15. WHO. Oral Health Surveys. Basic Methods. 4th ed. Geneva: World Health Organization; 1997.

16. Caufield PW, Li Y, Bromage TG. Hypoplasia-associated severe early childhood caries-a proposed definition. J Dent Res 2012; 91: 544-50. [CrossRef]

17. Gokalp S, Dogan G, Tekcicek M, Berberoğlu A, Unluer S. The Oral Health Profile of 5,12 and 15 Year Olds, Turkey-2004. Hacettepe Dis Hekimligi Fakultesi Dergisi 2007; 31: 3-10.

18. Olmez S, Uzamis M, Erdem G. Association between early childhood caries and clinical, microbiological, oral hygiene and dietary variables in rural Turkish children. Turk J Pediatr 2003; 45: 231-6.

19. Aimutis WR. Lactose cariogenicity with an emphasis on childhood dental caries. International Dairy Journal 2012; 22: 1528. [CrossRef]

20. Gopal S, Chandrappa V, Kadidal U, Rayala C, Vegesna M. Prevalence and Predictors of Early Childhood Caries in 3- to 6-year-old South Indian Children-A Cross-sectional Descriptive Study. Oral Health Prev Dent 2016; 14: 267-73.

21. Subramaniam P, Prashanth P. Prevalence of early childhood caries in 8-48 month old preschool children of Bangalore city, South India. Contemp Clin Dent 2012; 3: 15-21. [CrossRef]

22. Ozer S, Sen Tunc E, Bayrak S, Egilmez T. Evaluation of certain risk factors for early childhood caries in Samsun, Turkey. Eur J Paediatr Dent 2011; 12: 103-6.

23. Reisine S, Douglass JM. Psychosocial and behavioral issues in early childhood caries. Community Dent Oral Epidemiol 1998; 26: 32-44. [CrossRef] 
24. Ozen B, Van Strijp AJ, Ozer L, Olmus H, Genc A, Cehreli SB. Evaluation of Possible Associated Factors for Early Childhood Caries and Severe Early Childhood Caries: A Multicenter CrossSectional Survey. J Clin Pediatr Dent 2016; 40: 118-23. [CrossRef]

25. Mohebbi SZ, Virtanen JI, Murtomaa H, Vahid-Golpayegani M, Vehkalahti MM. Mothers as facilitators of oral hygiene in early childhood. Int J Paediatr Dent 2008; 18: 48-55.

26. King NM, Wu, II, Tsai JS. Caries prevalence and distribution, and oral health habits of zero- to four-year-old children in Macau, China. J Dent Child (Chic) 2003; 70: 243-9.

27. Ayhan H. Influencing factors of nursing caries. J Clin Pediatr Dent 1996; 20: 313-6.

28. Mattila ML, Rautava P, Sillanpaa M, Paunio P. Caries in fiveyear-old children and associations with family-related factors. J Dent Res 2000; 79: 875-81. [CrossRef]

29. Litt MD, Reisine S, Tinanoff N. Multidimensional causal model of dental caries development in low-income preschool children. Public Health Rep 1995; 110: 607-17.
30. Zanata RL, Navarro MF, Pereira JC, Franco EB, Lauris JR, Barbosa SH. Effect of caries preventive measures directed to expectant mothers on caries experience in their children. Braz Dent J 2003; 14: 75-81. [CrossRef]

31. Sheehy E, Hirayama K, Tsamtsouris A. A survey of parents whose children had full-mouth rehabilitation under general anesthesia regarding subsequent preventive dental care. Pediatr Dent 1994; 16: 362-4.

32. Mumcu G, Sur H, Yildirim C, Soylemez D, Atli H, Hayran O. Utilisation of dental services in Turkey: a cross-sectional survey. Int Dent J 2004; 54: 90-6. [CrossRef]

33. Topaloglu-Ak A, Eden E, Frencken JE. Managing dental caries in children in Turkey-a discussion paper. BMC Oral Health 2009; 9: 32. [CrossRef]

34. Dogan D, Dulgergil CT, Mutluay AT, Yildirim I, Hamidi MM, Colak H. Prevalence of caries among preschool-aged children in a central Anatolian population. J Nat Sci Biol Med 2013; 4: 325-9. [CrossRef] 